\title{
Possible Involvement of Beta-Adrenergic Receptors on Nociceptin/Orphanin FQ Induced Food Consumption in Male Rats
}

\author{
Mohammad Reza Hajinezhad, ${ }^{1, *}$ and Bahram Shohreh ${ }^{2}$ \\ ${ }^{1}$ Department of Basic Veterinary Sciences, Faculty of Veterinary Medicine, University of Zabol, Zabol, IR Iran \\ ${ }^{2}$ Department of Animal Sciences, Sari University of Agricultural Sciences and Natural Resources, Sari, IR Iran \\ "Corresponding author: Mohammad Reza Hajinezhad, Department of Basic Veterinary Sciences, Faculty of Veterinary Medicine, University of Zabol, Zabol, IR Iran. E-mail: \\ hajinezhad@gmail.com
}

Received 2015 May 10; Accepted 2015 May 10.

\begin{abstract}
Background: The nociceptin/orphanin FQ (N/OFQ) peptide is the endogenous ligand for the N/OFQ peptide (NOP) receptor. Beta adrenergic receptors and N/OFQ are involved in the regulation of food intake through central and peripheral mechanisms.

Objectives: The aim of this study was to determine the possible interaction between beta adrenergic and N/OFQ receptors on food consumption in male rats. N/OFQ agonists have been shown to increase food intake in mammals and birds. Beta adrenergic receptors physiologically inhibit food intake in mammals.

Methods: In this experimental study were used male rats (250-300 g). In first two experiments, rats received intraperitoneal injections of isoproterenol $(0,0.5,1$ and $2 \mathrm{mg} / \mathrm{kg})$ and Nociceptin agonist 64 - $6198(0,1,2$ and $4 \mathrm{mg} / \mathrm{kg})$ respectively. In third experiment $64-6198(4 \mathrm{mg} / \mathrm{kg})$ and $(2 \mathrm{mg} / \mathrm{kg})$ isoproterenol were injected. In experiments 4 effects of isoproterenol $(0.5 \mathrm{mg} / \mathrm{kg})$ and $\mathrm{Nociceptin}$ antagonist $(8 \mathrm{mg} / \mathrm{kg}$ ) on food consumption was investigated. Latency time to feeding was examined in experiment 5 . The data were statistically analyzed using One-way ANOVA and Tukey test.

Results: Latency time to feeding increased and decreased by isoproterenol and nociceptin/orphanin, respectively. Administration of $\mathrm{N} / \mathrm{OFQ}$ increased cumulative food intake in rats $(\mathrm{P}<0.05)$. The i.p. injection of isoproterenol decreased food intake and also the hyperphagic effect of N/OFQ agonist is inhibited by isoproterenol, whereas sub-anorectic doses of isoproterenol and N/OFQ antagonist synergistically attenuated cumulative feed consumption when combined $(\mathrm{P}<0.01)$.

Conclusions: On the basis of these findings, it can be concluded that isoproterenol may decrease food intake in rats by reduction in the N/OFQ content.
\end{abstract}

Keywords: Food intake, Isoproterenol, Nociceptin/Orphanin FQ' Rat

\section{Background}

Appetite control and energy balance regulation is modulated by a close interplay between hormonal and neuronal signaling. It has been demonstrated that catecholamines (including dopamine, epinephrine, and norepinephrine), have various effects on appetite control and metabolism [1]. Beta adrenergic receptors (or $\beta$ receptors) belong to the guanine nucleotide-binding $\mathrm{G}$ proteincoupled receptor (GPCR) superfamily. These receptors have multiple physiological effects in different tissues and play an important role in controlling appetite, thermoregulation, arterial pressure and heart rate [2].

The results obtained from previous studies have shown that beta-receptor antagonists stimulate food consumption in rats [3]. It would seem that the anorectic effects of $\beta$ receptors in mammals are in contrast with other vertebrates [4]. Isoproterenol is a non-selective beta adrenergic agonist. In the peripheral nervous system, as well as the brain, isoproterenol appears to have only beta-adrenergic activity. High dosages of beta adrenergic receptor agonists induce cardiomyocyte necrosis and interstitial fibrosis in rats [5]. Our preliminary results from similar studies on food and water consumption suggest that peripheral injections of isoproterenol, increased food and water consumption and this effect was blocked by i.p. injection of propranolol [6]. Peripheral, but not central anorectic effect of isoproterenol is mediated by beta adrenergic receptors. As reported by previous studies these effects are not related to sensory information transmitted via the vagus nerve [7]. The mechanism underlying the beta receptors induced hypophagia is still unclear, although the anorexic effect of beta receptors was reported to be mediated by serotonin but not histamine [8]. Nociceptin/orphanin FQ (N/OFQ) is endogenous ligand for the opioid-like GPCR1 or nociceptin receptor (NOP). In 1994, an unknown receptor which displayed no affinity for endogenous opioid was cloned. This receptor was named ORL1 (Opioid Receptor Like1). The endogenous ligand of the NOP receptor is a 17 amino acid pep- 
tide that owing to its hyperalgesic effects, this peptide was called nociceptin or orphanin FQ (hereafter called N/OFQ) [9]. Central injection of Nociceptin/orphanin FQ, amplifies food intake in rat [10]. Nociceptin stimulates feeding behavior and suppressed energy expenditure in laboratory rodents, in sum, these findings support the idea that $\mathrm{N} / \mathrm{OFQ}$ contributes to the regulation of energy balance [11].

It has been shown that, intracerebroventricular injection of N/OFQ into some brain nuclei increases food intake in birds [12]. Intracerebroventricular (ICV) injection of Nociceptin/orphanin FQ induces feeding can be blocked by opioid receptor antagonist, naloxone [13]. On the basis of these findings and considering the effects of isoproterenol and N/OFQ on feeding behavior in rats, it can be hypothesized that beta adrenergic system possibly mediates N/OFQ signaling in the hypothalamus of rats.

\section{Objectives}

Thus, the present study was designed to investigate whether blocking or stimulating N/OFQ receptor can influence beta adrenergic-induced feeding response in fooddeprived rats.

\section{Methods}

This experimental study was conducted in March-April 2015, on Department of basic veterinary science, university of Zabol, Iran.

\subsection{Animals}

Forty-eight adult male wistar rats (250 - $300 \mathrm{~g})$ from our own breeding colony were used. Experimentally naïve rats were used in first experiment. These animals were combined and used again in second experiment. An additional twelve naive rats were used in experiment 3 and subsequently reused in experiments 4 and 5 . All animals were individually put in separate cage with free access to tap water and food (Javaneh-Korasan, Iran), at $21-22^{\circ} \mathrm{C}$, humidity approximating 56\%, and 12 (h) light/dark cycles. The cumulative food intake by each rat was monitored throughout the experiments. All procedures used in the present study were performed according to the guide for the care and use of laboratory animals (from NIH Publication No.85-23) and also with the current ethical codes of our university.

\subsection{Drugs}

Drugs used in the experiment included isoproterenol, nociceptin agonist (64 - 6198) and nociceptin receptor antagonist (Nphe1) nociceptin (1 - 13) NH2 which were purchased from Tocris biosciences (Ellisville, MO 63021) and diluted in pyrogen-free $0.9 \% \mathrm{NaCl}$ solution (saline) that served as control. Doses of drugs were chosen on the basis of preliminary experiments and previous studies $[14,15]$.

\subsection{Experimental Procedures}

To determine the involvement of $\mathrm{N} / \mathrm{OFQ}$ receptor in the in adrenergic-induced eating response, effects of peripherally administered N/OFQ agonist and antagonist on adrenergic-induced eating response were determined in rats. All solutions, in one experiment, were injected on the same day and the feeding behavior was monitored before the injections. The rats were removed from their individual cages, restricted by hand, and after injections were put back in to their cages. Rats were handled and mockinjected daily during the 5 days recovery period to habituate them to the injection procedure. Twelve hours before the beginning of the experiments, rats were deprived of food but with water ad lib. Immediately after injections, the rats were returned to their cages. Fresh food was supplied at the time of injection, and cumulative feed intake (grams) was recorded at 120 and 240 minutes post injection. Food intake was measured by weighing the food containers.

Experiment 1 was designed to examine the effect of i.p. injections of different doses of isoproterenol on cumulative feed intake in food deprived rats. For this purpose, the rats received $0.5,0.1$ and $0.2 \mathrm{mg} / \mathrm{kg}$ of isoproterenol. In the peripheral nervous system, this drug is known to have beta-adrenergic activity. Control group was injected with $0.5 \mathrm{~mL}$ of $0.9 \% \mathrm{NaCl}$ solution. Experiment 2: Effect of i.p. injection of various doses of nociceptin agonist on food intake. The procedure was similar to experiment 1, except that rats received injections of saline and N/OFQ agonist (64 - 6198) 10, 20 and $4 \mathrm{mg} / \mathrm{kg}$ (each in a $0.5 \mathrm{~mL}$ volume). In experiment 3 , rats received two injections. The first injection consisted of either 0 or $4 \mathrm{mg} / \mathrm{kg}$ of 64 - 6198 in a volume of $0.5 \mathrm{~mL}$. The second injection consisted of either 0 or $2 \mathrm{mg} / \mathrm{kg}$ isoproterenol in a volume of $0.5 \mathrm{~mL}, 15$ minutes after the first injection as described in Table 1.

Experiment 4 was conducted similarly to previous experiment except that the first injection consisted of subanorectic dose $(0.5 \mathrm{mg} / \mathrm{kg})$ of isoprotrenol and the second injection consisted of $8 \mathrm{mg} / \mathrm{kg}$ of N/OFQ antagonist (Nphe1) nociceptin (1-13) NH2 (each in a $5 \mu$ L volume). The dose was determined from preliminary studies. In all experiments, in control groups, saline was used, in the same volume and times of i.p. injections as in the treated groups.

Experiment 5: Delay time for food consumption after i.p. injection of isoproterenol, N/OFQ agonist (64 - 6198), and antagonist was measured in 12 -h food-deprived rats. 


\subsection{Statistical Analysis}

Cumulative feed intake is presented as mean \pm SD and analyzed using a one-way analysis of variance (ANOVA) at each time period. For treatment showing a main effect by ANOVA, means have been compared by post hoc Tukey test. The values were considered significantly different when $P$ $<0.05$ (SPSS-17 for windows, SPSS Inc, Chicago, USA)

\section{Results}

The food intake response to i.p. injection of isoprotrenol, 64 - 6198, and N/OFQ antagonist in rats is presented in figures 1, 2, 3 and 4. In experiment 1, the i.p. injection of isoprotrenol of food-deprived rats caused a dosedependent decrease in food consumption (Figure $1, \mathrm{P}<$ 0.001 ). The $0.6 \mathrm{mg} / \mathrm{kg}$ isoprotrenol dose was selected for the following experiment because it was found to decrease food intake in rats without affecting other behavioral parameters. In experiment 2, i.p. injection of $4 \mathrm{mg} / \mathrm{kg} 64$ 6198 alone increased food intake in food deprived rats (Figure $2, \mathrm{P}<0.05)$. As it is observed in Figure 3, pretreatment with isoprotrenol $(2 \mathrm{mg} / \mathrm{kg})$ completely abolished the effect of $64-6198(4 \mathrm{mg} / \mathrm{kg})$ on food intake observed 120 and 240 min post treatment. The results of experiment 4 showed that the inhibitory effect of isoprotrenol on cumulative food intake was significantly increased by $8 \mathrm{mg} / \mathrm{kg}$ nociceptin antagonist pretreatment, probably in an additive manner (Figure $4, \mathrm{P}<0.01$ ). Delay time for food consumption significantly decreased after i.p. injection of $\mathrm{N} / \mathrm{OFQ}$ agonist and increased after administration of isoproterenol (Table $2, \mathrm{P}<0.01$ ).

Figure 1. Cumulative Food Intake (g) in Rats Following i.p. Injection of Saline and Different Doses of Isoproterenol

\section{Foot Intake (g)}

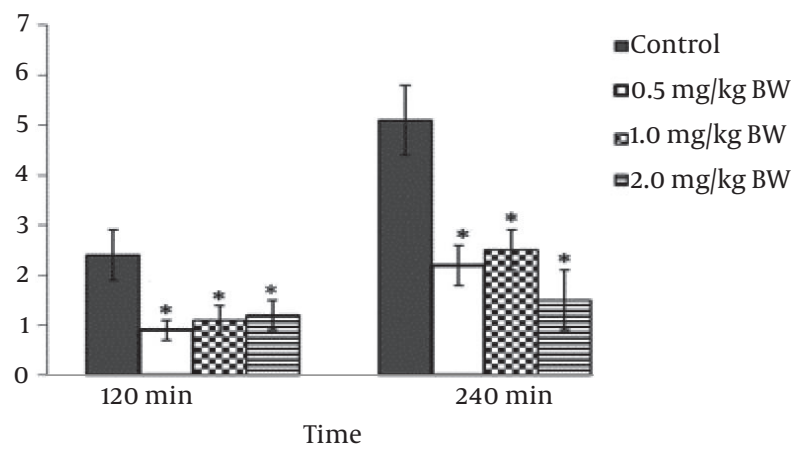

Data are presented as mean \pm SD. ${ }^{*}$ means $\mathrm{P}<0.001$ vs. Control.
Figure 2. Effect of Intraperitoneal Injection of Different Doses of N/OFQ Agonist (64 -6198) on Cumulative Feed Intake in Food-Deprived Rats

Foot Intake ( $g)$

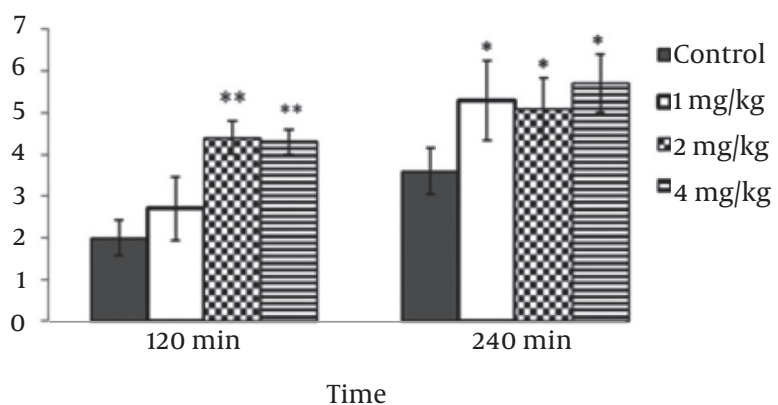

Data are presented as mean $\pm \mathrm{SD} .{ }^{*}$ means $\mathrm{P}<0.05$ vs. Control; ${ }^{* *}$ means $\mathrm{P}<0.001$ vs. Control.

Figure 3. Effect of Intraperitoneal Injection of Isoprotrenol ( $2 \mathrm{mg} / \mathrm{kg})$ Followed by 4 $\mathrm{mg} / \mathrm{kg}$ N/OFQ Agonist (64 - 6198) on Cumulative Feed Intake in Food-Deprived Rats

Foot Intake $(\mathrm{g})$

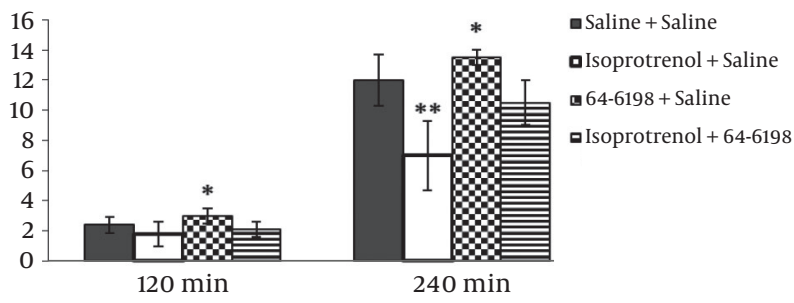

Data are presented as mean \pm SD. * means $\mathrm{P}<0.05$ vs. Control; ** means $\mathrm{P}<0.01$ vs. Control.

Figure 4. Effect of Intraperitoneal Injection of Isoprotrenol $(0.5 \mathrm{mg} / \mathrm{kg})$ Followed by $\mathrm{N} / \mathrm{OFQ}$ Antagonist ( $8 \mathrm{mg} / \mathrm{kg}$ ) on Cumulative Feed Intake in 12-h Food-Deprived Rats

Foot Intake $(\mathrm{g})$

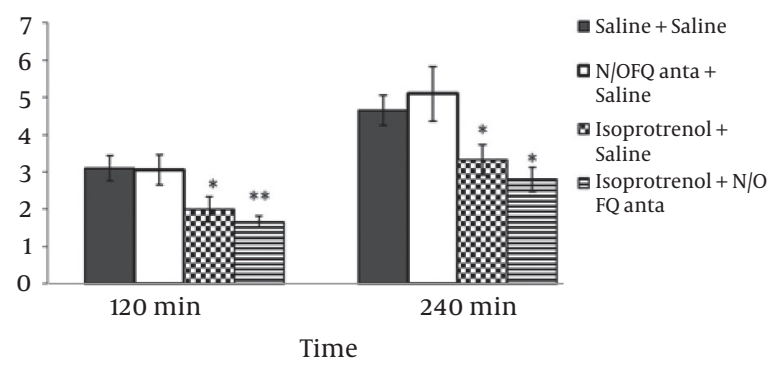

Data are presented as mean $\pm \mathrm{SD}$. * means $\mathrm{P}<0.05 \mathrm{vs.} \mathrm{Control;} \mathrm{**} \mathrm{means} \mathrm{P}<0.01 \mathrm{vs}$. Control.

\section{Discussion}

The present study shows that the peripheral injection of the beta-adrenergic agonist alone caused a hypophagic 
Table 1. Treatment Procedures in Experiment 3

\begin{tabular}{|c|c|c|}
\hline First injection & Second Injection & Treatments \\
\hline Saline, $0.5 \mathrm{~mL}$ & Saline (0.5 mL) & Saline + Saline $\mathrm{e}^{\mathrm{a}}$ \\
\hline Saline , $0.5 \mathrm{~mL}$ & Isoproterenol ( $2 \mathrm{mg} / \mathrm{kg})$ & Saline + Isoproterenol \\
\hline Saline, $0.5 \mathrm{~mL}$ & $64-6198(4 \mathrm{mg} / \mathrm{kg})$ & Saline $+64-6198$ \\
\hline Isoprotrenol, 2 mg/kg & $64-6198(4 \mathrm{mg} / \mathrm{kg})$ & Isoproterenol + $64-6198$ \\
\hline
\end{tabular}

Table 2. Latency Time to Feeding After Intraperitoneal Injection of Isoproterenol, N/OFQ Agonist, and Antagonist in 12-h Food-Deprived Rats

\begin{tabular}{|c|c|c|}
\hline Latency of feeding in rats ( $\mathrm{min}$ ) & Mean \pm SD & Range \\
\hline Saline, $0.5 \mathrm{~mL}$ & $15.2 \pm 2.3$ & $12.2-17.4$ \\
\hline Isoproterenol, $0.2 \mathrm{mg} / \mathrm{kg}$ & $23.1 \pm 4.2^{\mathrm{a}}$ & $19.4-27.5$ \\
\hline $64-6198,4 \mathrm{mg} / \mathrm{kg}$ & $8.2 \pm 2.1^{\mathrm{a}}$ & $6.3-10.2$ \\
\hline N/OFQ antagonist, $8 \mathrm{mg} / \mathrm{kg}$ & $16.5 \pm 4.24$ & $11.2-20.4$ \\
\hline
\end{tabular}

${ }^{\mathrm{a}}$ Significant with respect to control group $(\mathrm{P}<0.01)$.

effect accompanied by an increase in the latency to start eating. Similar result was obtained in a previous study after administration of beta 3 adrenergic receptor agonist [16].

This leads us to the conclusion that beta-adrenergic receptor inhibit feeding of animals in a normal feeding condition. There is evidence that norepinephrine (NE) plays an important role in the control of feeding behavior. Peripheral and central administration of norepinephrine stimulates feeding in mammals. Any alteration of noradrenaline release can increase or decrease eating, depending on the site of application and other testing variables [17]. Intraperitoneal injection of 64 - 6198 significantly increased food intake and decreased latency time to feeding over specified period of time (Figure 2). The results obtained from experiment 2 are consistent with previous studies reported in which systematic or ICV administration of N/OFQ strongly increase food intake in rats [18]. The decrease in food intake, when nociceptin antagonist is injected, suggests that a NOP receptor antagonist not only can abolish the effect of nociceptin on food intake but also might make more constitutive-released endogenous nociceptin. This conclusion may be overturned by further research. Further investigations should be carried out to examine the possible effect of NOP receptor agonists when beta-adrenoceptors are blocked, the effect of beta 1 , beta 2 and beta 3-receptors and the interaction between endogenous nociceptin and beta adrenergic circuitry, especially in central mechanisms regulating food intake intake, will also be the potential subjects for future studies. Periph- eral stimulation of beta adrenergic receptors was shown to prevent hyperphagic effects of N/OFQ agonist (64 - 6198), suggesting a possible interaction between them. These results indicate that both N/OFQ and beta-adrenergic receptors are involved in regulatory centers of feeding. In the mammals, it seems that ghrelin signals travel through vagus nerve to nucleus of tractus solitaries in brain stem and regulates noradrenaline release via $\alpha 1$ and $\beta 2$ receptors. There is evidence that the adrenergic system plays a role in regulation of feeding. It is well known that the direct isoprotrenol-induced activation of adrenergic fibers in the brainstem is paralleled by an inhibitory synaptic effect on $\alpha$-melanocyte stimulating hormone neurons of the ventrolateral arcuate nucleus [19]. The central orexigenic effect of N/OFQ in rats is not well understood but recent studies suggest that N/OFQ increases food consumption in a manner similar to GABA receptors and opioid peptides [20]. Furthermore, both beta-adrenergic and N/OFQ receptors, has been shown to exist in various regions of the brain $[21,22]$. However, the sites within the brain involved in the action of either beta adrenergic or N/OFQ and therefore their interaction, remains to be clarified. It could be concluded that peripheral administration of isoprotrenol induces a hypophagia by reduction in the N/OFQ content. Understanding the mechanisms of beta adrenergic receptors in the regulation of appetite is a key component for any weight management program. On the other hand, new research about nociceptin receptors may lead to a new strategy for the treatment of anorexia. The interaction between peripheral beta-receptors and nociceptin on regulation of 
food intake has not been fully studied. This work, therefore, provides information on the effect of beta-adrenergic and nociceptin on food intake in food deprived rats. Our findings suggest that N/OFQ has stimulatory effect on food intake in rats as observed in mammals and isoprotrenol has inhibitory effect on food intake.One possibility is that the inhibitory effect of isoproterenol may involve reduction in the N/OFQ content but further works will be needed to be carried out.

This study demonstrates a synergistic interaction between the effects of isoproterenol and nociceptin antagonist on feeding, provide further evidence of important functional relationships between endogenous ligand of the NOP receptor and beta adrenergic system.

\section{Acknowledgments}

This study was financed by Grant 03-1394-07 of the department of animal sciences, Sari Agricultural Sciences University Sari, Iran. We are grateful to technician staffs of the laboratory animal centre of university of Zabol, for their excellent technical assistance and animal care.

\section{Footnotes}

Authors' Contribution: Dr. Shohreh provided the chemical substances and designed the study, Dr. Hajinezhad developed the methodology and wrote the manuscript.

Funding/Support: Sari Agricultural Sciences University.

\section{References}

1. Jonaidi H, Hajinezhad MR, Salari S. Effects of intra-cerebro-ventricular ghrelin with or without nociceptin on feed intake in Ross cockerels. Online J Vet Res. 2014;18(7):563-71.

2. Ferrara N, Komici K, Corbi G, Pagano G, Furgi G, Rengo C, et al. betaadrenergic receptor responsiveness in aging heart and clinical implications. Front Physiol. 2014;4:396. doi: 10.3389/fphys.2013.00396. [PubMed: 24409150].

3. Zendehdel $M$, Shain $H$. Central regulation of food intake in mammals and birds: A review. Neurotransmitter. 2014;1(1):1-7.

4. Bachman ES, Dhillon H, Zhang CY, Cinti S, Bianco AC, Kobilka BK, et al. betaAR signaling required for diet-induced thermogenesis and obesity resistance. Science. 2002;297(5582):843-5. doi: 10.1126/science.1073160. [PubMed: 12161655].

5. Baghbanzadeh A, Hajinezhad MR, Shohreh B, Maleklou R. Intralateral hypothalamic area injection of isoproterenol and propranolol affects food and water intake in broilers.J Comp Physiol A Neuroethol Sens Neural Behav Physiol. 2010;196(3):221-6. doi: 10.1007/s00359-010-0507-7. [PubMed: 20140677].

6. DoustarY, Mohajeri D. The anti-apoptotic effects of atorvastatin in isoproterenol induced experimental heart failure. Zahedan J Res Med Sci. 2011;13(2):13-9.
7. Brandt K, Arnold M, Geary N, Langhans W, Leonhardt M. Vagal afferents mediate the feeding response to mercaptoacetate but not to the beta (3) adrenergic receptor agonist CL 316,243. Neurosci Lett. 2007;411(2):104-7. doi: 10.1016/j.neulet.2006.10.034. [PubMed: 17112664].

8. Backberg M, Ultenius C, Fritschy JM, Meister B. Cellular localization of GABA receptor alpha subunit immunoreactivity in the rat hypothalamus: relationship with neurones containing orexigenic or anorexigenic peptides. J Neuroendocrinol. 2004;16(7):589-604. doi: 10.1111/j.1365-2826.2004.01207.x. [PubMed: 15214862].

9. Olszewski PK, Levine AS. Minireview: Characterization of influence of central nociceptin/orphanin FQ on consummatory behavior. Endocrinology. 2004;145(6):2627-32. doi: 10.1210/en.2004-0016. [PubMed: 15044361].

10. Polidori C, de Caro G, Massi M. The hyperphagic effect of nociceptin/orphanin FQ in rats. Peptides. 2000;21(7):1051-62. [PubMed: 10998540].

11. Bedini A, Spampinato SM. Role of nociceptin/orphanin FQ in thermoregulation. Neuropeptides. 2015;50:51-6.

12. Tajalli S, Jonaidi H, Abbasnejad M, Denbow DM. Interaction between nociceptin/orphanin FQ (N/OFQ) and GABA in response to feeding. Physiol Behav. 2006;89(3):410-3. doi: 10.1016/j.physbeh.2006.07.009. [PubMed: 16904711].

13. Olszewski PK, Grace MK, Sanders JB, Billington CJ, Levine AS. Effect of nociceptin/orphanin FQ on food intake in rats that differ in diet preference. Pharmacol Biochem Behav. 2002;73(3):529-35. [PubMed: 12151026].

14. Miranda M, Pautassi R. Pharmacological characterization of the nociceptin/orphanin FQ receptor on ethanol-mediated motivational effects in infant and adolescent rats. Behave Brain Res. Behav Brain Res. 2016;298:88-96.

15. Baiula M, Bedini A, Spampinato SM. Role of nociceptin/orphanin FQ in thermoregulation. Neuropeptides. 2015;50:51-6. doi: 10.1016/j.npep.2015.03.005. [PubMed: 25812480].

16. Kanzler SA, Januario AC, Paschoalini MA. Involvement of beta3adrenergic receptors in the control of food intake in rats. Braz J Med Biol Res. 2011;44(11):1141-7. [PubMed: 21971689].

17. Mansur SS, Terenzi MG, Marino Neto J, Faria MS, Paschoalini MA. Alpha1 receptor antagonist in the median raphe nucleus evoked hyperphagia in free-feeding rats. Appetite. 2011;57(2):498-503. doi: 10.1016/j.appet.2011.06.017. [PubMed: 21745511].

18. Lowell BB, Bachman ES. Beta-Adrenergic receptors, diet-induced thermogenesis, and obesity. J Biol Chem. 2003;278(32):29385-8. doi: 10.1074/jbc.R300011200. [PubMed: 12788929].

19. Battistoni S, Kloting I, Cifani C, Massi M, Polidori C. Gender differences in Nociceptin/Orphanin FQ-induced food intake in strains derived from rats prone (WOKW) and resistant (Dark Agouti) to metabolic syndrome: a possible involvement of the cocaine- and amphetamine-regulated transcript system. Genes Nutr. 2011;6(2):197202. doi: 10.1007/s12263-010-0189-3. [PubMed: 21484154].

20. Zendehdel M, Hassanpour S. Ghrelin-induced hypophagia is mediated by the beta2 adrenergic receptor in chicken. J Physiol Sci. 2014;64(5):383-91. doi: 10.1007/s12576-014-0330-y. [PubMed: 25080314].

21. Roberto M, Siggins GR. Nociceptin/orphanin FQ presynaptically decreases GABAergic transmission and blocks the ethanol-induced increase of GABA release in central amygdala. Proc Natl Acad Sci U S A. 2006;103(25):9715-20. doi: 10.1073/pnas.0601899103. [PubMed: 16788074].

22. Brandt K, Arnold M, Geary N, Langhans W, Leonhardt M. Betaadrenergic-mediated inhibition of feeding by mercaptoacetate in food-deprived rats. Pharmacol Biochem Behav. 2006;85(4):722-7. doi: 10.1016/j.pbb.2006.11.002. [PubMed: 17175014]. 